\title{
引張・曲げ疲労を受ける部材の 安全性評価に関寸る一考察
}

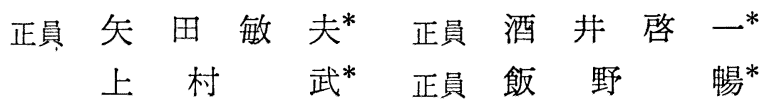

A Study on safety assessment of structural members subjected

to combined tensile and bending stress fatigue

$\begin{array}{ll}\text { by Toshio Yada, Member } & \text { Keiichi Sakai, Member } \\ \text { Takeshi Uemura, } & \text { Nobu Iino, Member } \\ \text { Summary } & \end{array}$

Fatigue crack growth characteristics were investigated using center notched plate specimens. The results showed that the mean stress has effect on the growth rate and the growth rate can be expressed using following formula which takes the mean stress effect into account,

$$
d a / d N=C\left(K_{\max } / \Delta K\right)(\Delta K)^{m}
$$

Experimental work was also done to investigate fatigue crack propagation behavior of semielliptical surface cracks subjected to combined tensile and bending stresses. Off-centered plate specimens with mechanically introduced surface cracks were used for this test. Estimation on fatigue crack growth was then made on such cracks applying the results of theoretical analysis done by Shah and Kobayashi on stress intensity factor for semi-elliptical surface cracks. From the analysis, it was found that the larger the amount of bending the longer the extension is along the surface. Experimental results showed similar trend to analytical results with respect to fatigue crack front configurations.

These results were taken into account to discuss safety in liquid containers on the basis of leak before failure concept.

\section{1 緒 言}

構造物の安全性を保証するうえで，応力の繰返しに対する構造部材の疲労特性を把握しておくことは重要であ る。

疲労現象については, 疲労き裂の発生と疲労き裂の進展の問題に便宜的に分けて考学られる。応力変動を受け る構造物の設計に際しては, 構造各部の応力の変動と繰返し条件と瘦労強度線図とを比较し設計条件を検討する ことが必要である。この立場からは疲労き裂の発生の問題が重視される。しかしながら大形構造物においては, 設計的に算定される構造的不連続部などに生じる応力集中のほかに, 工作誤差による応力集中, 溶接部のアンダ 一カットや割れなどの疲労強度におよぼす不確定な要因があり，これらを全て考慮に入れて疲労強度を決定する ことはかなり困難である。一方，疲労き裂が発生したとしてもき裂が小さい初期段階では直接大破壊につながる とは限らず，供用中の検查あるいは何らかの検知方法でき裂を検出して処置がとられる以前に大破壊を生じなけ れば可とする Fail safe design の考え方が各分野で取入れられている。この考え方に拈いては, 疲学き裂の進 展特性が重視され, 疲労さ裂の進展拡大の速さとき裂の形状を脆性破壊あるいは延性破壊への遷移条件との関連 に特いて定量的に取扱ら必要がある。

\footnotetext{
* 石川島播磨重工業(株)技術研究所
} 
これらの 2 つの考方方は施工拉よび検査の難易あるいは経済性なども含め検討し，機種に応じぞちらに重点を 括くか決めるべき問題であろらが，初期欠陥を想定してき裂の進展を考兄，最終強度との関連に括いて安全性を 検討すれば安全性をより高めることになると考えられる。

液体貯槽などについては，漏れを生じるようなき裂を生じたとしても大破壊を生じないよう十分な切欠強度を もつことを前提として，Leak before failureの条件が適用される場合があるが，これは狭義の Fail safe design であり，疲労き裂については進展の速さと板厚を貫通する際の形状寸法が問題となる。

著者らは A 5083-0 材について疲労試験を行ない, き裂の進展速さと表面切欠から生じた疲労き裂の進展特性 について調べたので,ここに報告する。表面疲労き裂についてはすでに金沢らの研究1があるが，ここでは実際の 構造部材においては引張と曲げの組合せ応力を受ける場合があること，膜構造に括いても工作誤差あるいは板厚 の不連続などが存在する場合には引張応力のほかに曲げ応力を生じることを考慮して，引張と曲げとの組合せ応 力を受ける構造部材の疲労き裂進展特性を取上げた。またこれらの試験結果を近似解析し Leak before failure 条件を適用する際の問題点について考察した。

\section{2 実 験 的 研 究}

板厚 $25 \mathrm{~mm}$ 特よび $35 \mathrm{~mm}$ の A 5083-0 材を用い疲労き裂の進展特性を調べた。板厚貫通の切欠を加工した試 駼片による軸力痛労試験片により，き裂進展速さに関する基礎的試験を行なうとともに，引張軸を偏心させた表 面切欠つき試験片を用いて疲労試験を行ない，引張と曲げとの組合せ応力の絽返しに対する疲労き裂の進展挙動 について調べた。

\section{1 供 試 材}

供試材は市販の A 5083-0 材で, 析厚 $25 \mathrm{~mm}$ と $35 \mathrm{~mm}$ の 2 種類である。供試材の化学成分を Table 1 に, 機械的性質を Table 2 に示す。

\section{2 試験片の形状}

試験片の形状を Fig. 1 に示す。Fig. 1 (a) は Axial stress-through notch crack の実験（AT) に, Fig. 1 (b) は Combined stress-part through crack の実験（CP）に用いた。 CP 形試験片は試験片中央部之両端部 との厚さ中心を偏心させることにより，軸荷重により曲げモーメントを生じさせ，軸芯力と曲げとの組合せ応力 を与劣るようにしたるのである。この種の試験片で与えられる応力条件については後述する。

\section{3 試験条件と試験の方法}

AT 形および CP 形試験片の試験条件を Table 3 に示す。AT 形試験片については 40 ton サーボ疲労試験 機を使用し，CP 形試験片は 200 ton ローゼン形疲労試験機を用いて実駼した。

疲労き裂の進展速さの計測に関しては, AT 形では初期切欠に近接して試験片の表裏に 4 対のクラックダージ （フィラメント間隔 $1 \mathrm{~mm}$ または $0.2 \mathrm{~mm}$ ，共和電業(株)）を貼布し，試験を中断することなく計測し，所定の応

Table 1 Chemical composition

\begin{tabular}{l|c|c|c|c|c|c|c|c|c}
\hline \multirow{2}{*}{ Material } & $\begin{array}{c}\text { Thickness, } \\
\mathrm{mm}\end{array}$ & \multicolumn{7}{|c}{ Chemical composition } \\
\cline { 4 - 11 } & $\mathrm{Cu}$ & $\mathrm{Si}$ & $\mathrm{Fe}$ & $\mathrm{Mn}$ & $\mathrm{Mg}$ & $\mathrm{Zn}$ & $\mathrm{Cr}$ & $\mathrm{Ti}$ \\
\hline \multirow{3}{*}{ A5083-0 } & 25 & 0.03 & 0.13 & 0.17 & 0.69 & 4.61 & 0.01 & 0.13 & 0.01 \\
\cline { 2 - 10 } & 35 & 0.03 & 0.16 & 0.22 & 0.68 & 4.53 & 0.01 & 0.13 & 0.01 \\
\hline
\end{tabular}

Table 2 Mechanical properties

\begin{tabular}{c|c|c|c|c}
\hline $\begin{array}{c}\text { Thickness, } \\
\mathrm{mm}\end{array}$ & $\begin{array}{c}\text { Temperature, } \\
{ }^{\circ} \mathrm{C}\end{array}$ & $\begin{array}{c}0.2 \% \text { offset } \\
\text { yield strength } \\
\sigma_{0.2}, \mathrm{~kg} / \mathrm{mm}^{2}\end{array}$ & $\begin{array}{c}\text { Tensile strength } \\
\sigma_{T}, \mathrm{~kg} / \mathrm{mm}^{2}\end{array}$ & $\begin{array}{c}\text { Elongation, } \\
\%\end{array}$ \\
\hline 25 & 20 & 15.8 & 33.5 & 30.0 \\
& -196 & 18.3 & 44.0 & 32.0 \\
35 & 20 & 15.5 & 33.0 & 27.0 \\
\hline
\end{tabular}


Table 3 Test conditions for fatigue specimens

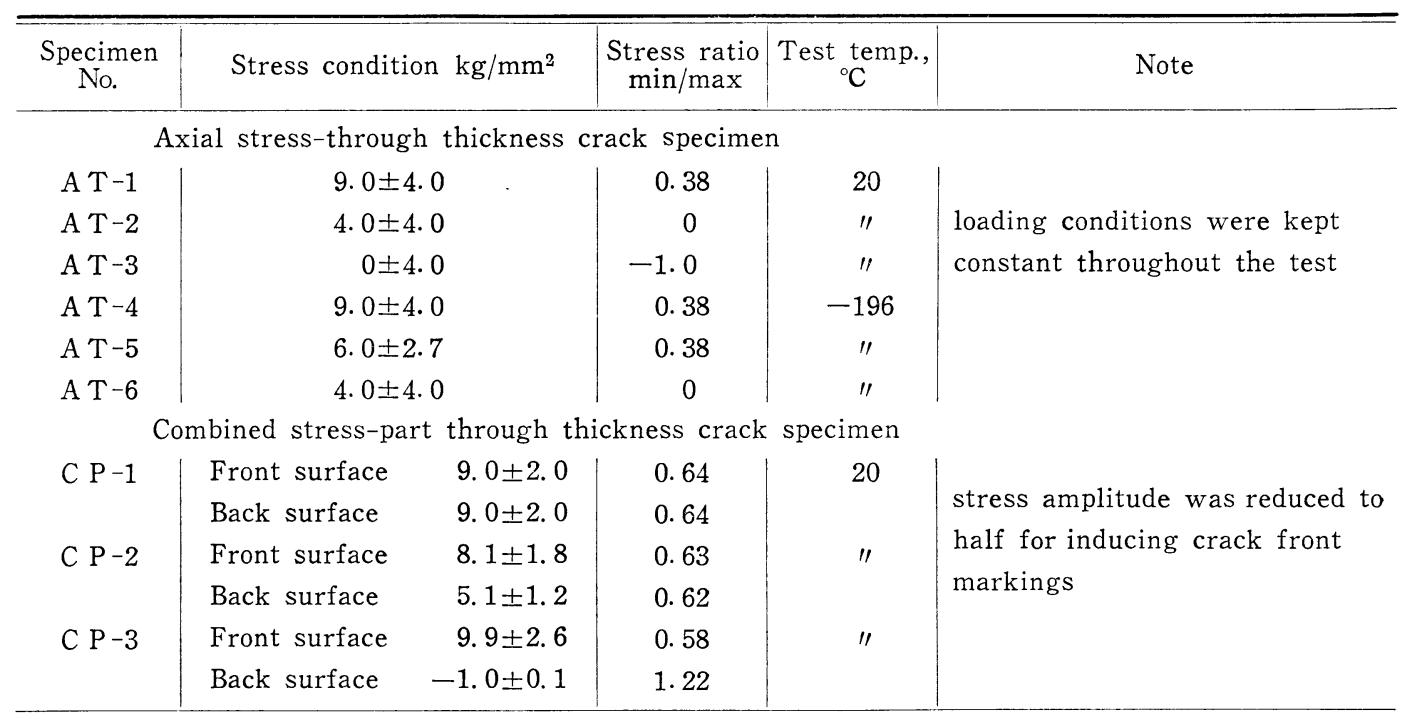

カの繰返し数 $(N)$ とさ裂長さの $1 / 2$ (a) との関係を求めた。

$\mathrm{CP}$ 形試験片については, 疲労試験 の途中で, 最大荷重を一定に保ったま ま振幅を約 $1 / 2$ 亿減じ $5 \times 10^{3} \sim 10^{4}$ 回 程度繰返すことにより, 疲労破面の先 端を示すマークを描かせ破断後の破面 を観察し, 繰返し数との対応をつけ た。

\section{4 実験結果}

AT 形試験片で得られたき裂長さ $a$ と回数 $N$ の plot から疲学き裂の進展 速さ $d a / d N$ を求め, 応力抎大係数 $K$ 值の全振幅 $\Delta K$ との関係を図示すると Fig. 2 のよらである。 $\Delta K$ の值は次式 により計算した。

$$
\begin{aligned}
& \Delta K=\Delta \sigma \cdot \sqrt{a} \cdot f(a / w) \\
& \text { ここで }
\end{aligned}
$$

$\Delta \sigma:$ Gross 応力の全振幅
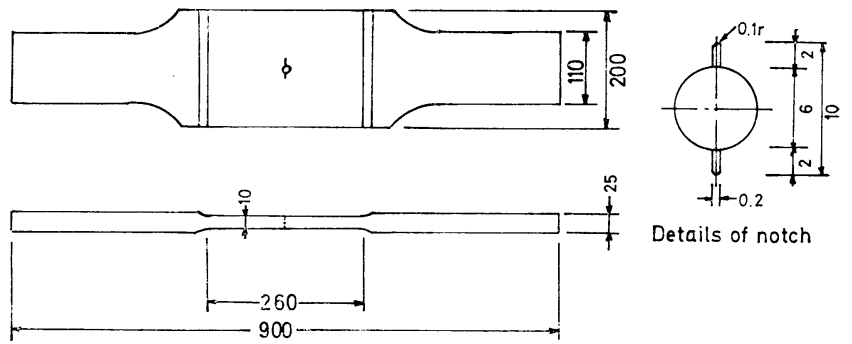

Details of notch

Fig. 1 (a) Specimen with a through thickness notch (AT specimen)
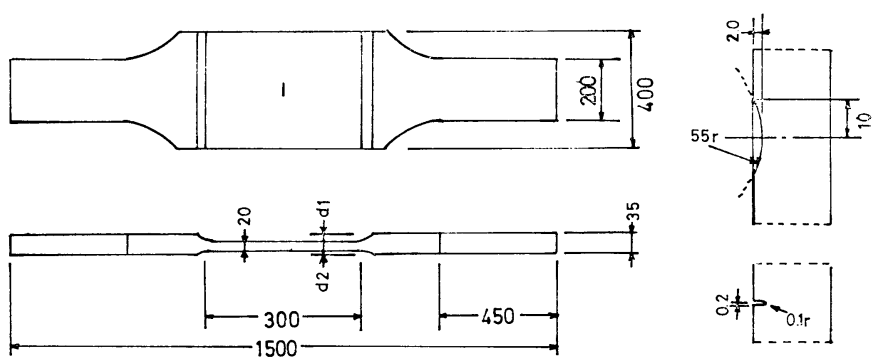

Details of notch

$2 a:$ き裂長さ

$2 w:$ 試験片の幅

Fig. 1 (b) Specimen with a surface notch having a dislocated axis in thickness direction (CP specimen)

$f(a / w)$ : 有限板の補正值

$$
=1.77+0.227(a / w)-0.51(a / w)^{2}+2.7(a / w)^{3}
$$

Fig. 3 は CP 形試験片の破面上に描かれたマークをスケッチしたもので, 疲労き裂の進展状況を示している と考えられる。図によれば, 表面切欠から生じた疲労き裂は棈円状に進展し板厚を貫通する。板厚を貫通した後 は, き裂の裏面側の進展速さが大きく, 表裏面の疲労き裂の差は急速に小さくなる。また, 引張と曲げの組合せ 応力で曲げ成分の大きいものほど，き裂形状が偏平になることが認められる。

Fig. 2 扣よび Fig. 3 中には計算で得られた曲線が合せて示してあるが，これらについては後述する。 


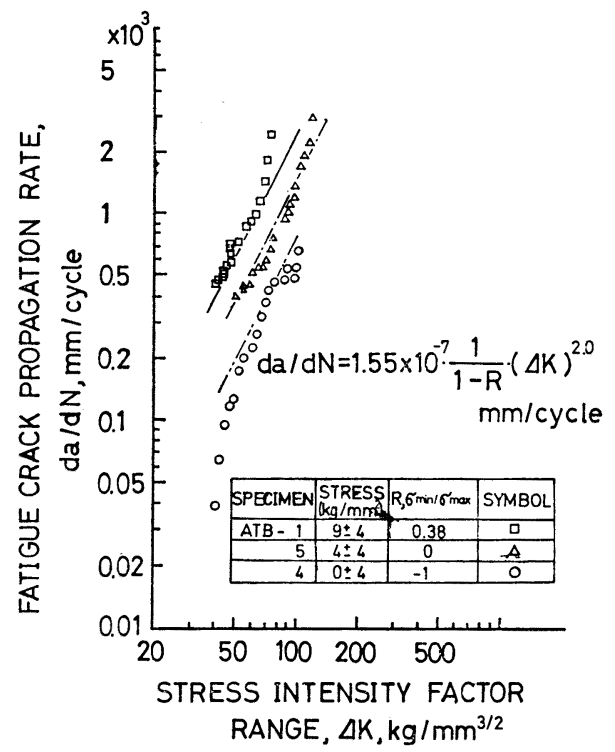

Fig. 2 (a) $d a / d N$ vs. $\Delta K$ for base metal $(5083-0)$ at $20^{\circ} \mathrm{C}$

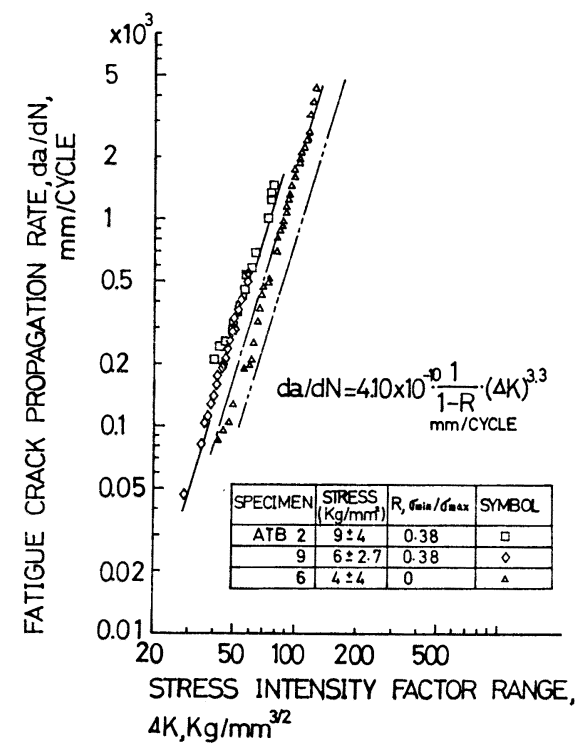

Fig. 2 (b) $d a / d N$ vs. $\Delta K$ for base metal (5083-0) at $-196^{\circ} \mathrm{C}$

NUMBER OF CYCLES

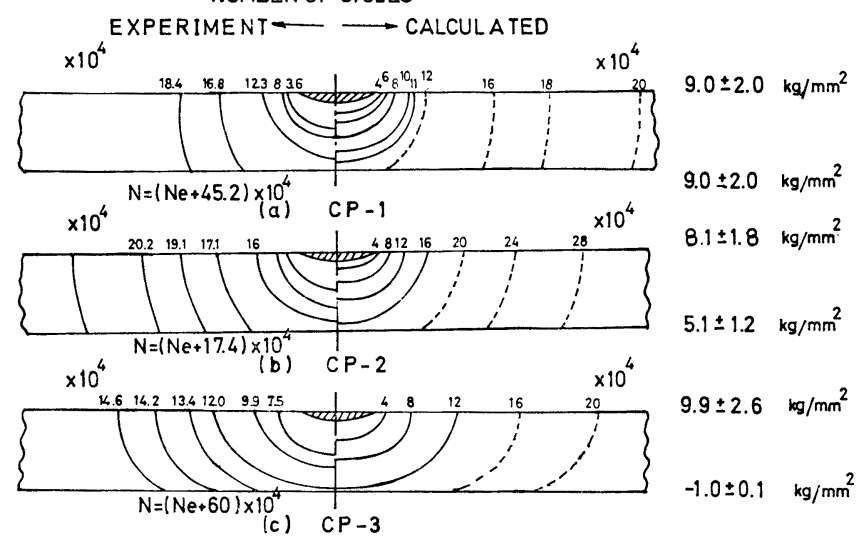

Fig. 3 (a, b, c) Comparison of experimental and calculated fatigue crack growth from a semi-elliptical surface crack

\section{3 疲労き裂の進展特性の解析}

\section{1 疲労き裂の進展におよぼす平均応力の影響}

疲労き裂の進展特性の定量化については多くの研究が行なわれているが，その汪とんぞが形式的には $K$ 值関 係づけた表示式を与えている。たとえば Paris ら²) は疲労き裂の進展速さの一般的表示式として次式を与えて いる。

$$
\frac{d a}{d N}=C \cdot(\Delta K)^{m}
$$

$$
\text { ここで }
$$

$$
\begin{gathered}
\Delta K: K \text { 値の全振幅 } \\
C, m: \text { 材料定数 }
\end{gathered}
$$

（2）式には平均応力の影響が考慮されていないが，この影響についても種々の定量化が試みられている。 L. Tall ${ }^{3)}$ は 


$$
\frac{d a}{d N}=C\left(\frac{K_{\max }}{\Delta K}\right) \cdot(\Delta K)^{m}
$$

ただし

$K_{\max }$ は $K$ の最大值

の表示式を提案している。このほか Forman らの表示式あるいは豊貞の crack opening displacement に注目 した提案4)などがある。的場ら゙) は Uchimoto らのアルミニウム合金 (2024-T 3，7075-T 6) に関する研究結果 ${ }^{6)}$ が(3)式でよく整理でさることを示している。

Fig. 2 に示す A 5083-0 材の室温拉よび低温に拈ける実験結果の plot によれば, (2) 式を適用して材料定数 を定めることは困難で，試験条件によって差がみられる。

AT 試験片では

$$
\left.\begin{array}{l}
K_{\max } / \Delta K=1 /(1-R) \\
R=\sigma_{\min } / \sigma_{\max }
\end{array}\right\}
$$

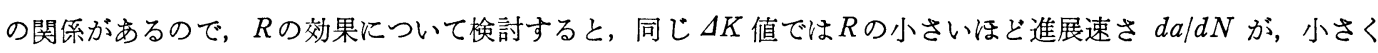
なること，Rが等しい試験片の進展速さがよく一致していることが認められる。いま（3）式を用いて材料定数 を定めるとそれぞれの試験条件に対して Fig. 2 (a) および (b) 中の各曲線を得る。な特材料定数の決定に際し ては後述の表面疲労さ裂の解析に関して平均応力が高く $\Delta K$ の小さい側の実験值を重視した。計算值は $R=-1$ の場合も含め実験值の plot と大略一致させることができた。な执試験片が全断面で降伏する際の $\Delta K$ 值は, $\Delta \sigma=8 \mathrm{~kg} / \mathrm{mm}^{2}$ のとき平均応力 $9,4,0 \mathrm{~kg} / \mathrm{mm}^{2}$ に対し約 $58,98,122 \mathrm{~kg} / \mathrm{mm}^{2} \sqrt{\mathrm{mm}}$ でありこれ以上の $\Delta K$ 值 に対しては，実験値の評価は困難であり，（3)式は適用できないと考えられる。

\section{2 引張と曲げとの組合せ応力を受ける表面切欠からの疲労き裂進展}

板厚貫通の疲労さ裂の進展速さを応力拡大係数 $K$ の変動幅 $\Delta K$ に基づいて整理し $(3)$ 式により表示すること ができた。表面切欠についても同様に，き裂先端の各位置でのK值を求めることができる。ここでは引張と曲げ の組合せ応力の変動を受ける表面半棈円さ裂について進展特性を解析する。

\section{(1) $K$ 值の計算}

Fig. 4 に示すよらな半楕円表面き裂が，引張と曲げを受ける場合の K值を A. S. Kobayashi の解7を利用して 求めると次のように書ける。

ここで

$$
\begin{aligned}
& K=\sqrt{\frac{\pi b}{a}}\left(a^{2} \cos ^{2} \beta+b^{2} \sin ^{2} \beta\right)^{1 / 4} \frac{1}{E(k)} \\
& \times\left[m_{1}\left\{\left(1+\frac{2 b}{t}\right) \cdot \frac{M t}{2 I}+\sigma_{n}\right\}-m_{2} \frac{2 b}{t} \cdot \frac{M t}{2 I}\left\{1-\frac{k^{2} \cdot E(k) \cos \beta}{\left(1+k^{2}\right) E(k)-k^{\prime 2} \cdot K(k)}\right\}\right]
\end{aligned}
$$

$$
\begin{aligned}
& k^{2}=\left(a^{2}-b^{2}\right) / a^{2} \\
& k^{\prime 2}=b^{2} / a^{2} \\
& K(k)=\int_{0}^{\pi / 2} \frac{d \beta}{\sqrt{1-k^{2} \sin ^{2} \beta}} \\
& E(k)=\int_{0}^{\pi / 2} \sqrt{1-k^{2} \sin ^{2} \beta} \cdot d \beta
\end{aligned}
$$

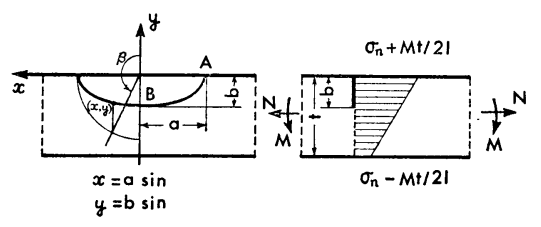

$\sigma_{n}:$ 引張応力

(a) Coordinate denoting a semi- (b) Nominal stress distribution elliptical crack in CP specimen

$M:$ 曲げモーメント

$I:$ 曲げ剛性

$t$ : 板 厚

Fig. 4 Schematic illustration of surface crack and stress distribution under combined tensile and bending stress

$\left.\begin{array}{rl}a, b & : \text { 楕円き裂の長軸, 短軸 } \\ \beta & : \text { 棈円き裂の短軸からの角度 }\end{array}\right\} \quad$ Fig. 4 参照

$m_{1}, m_{2}$ : 引張および曲げ応力に対する自由表面の影響数

（2）表面き裂からの進展特性の解析

疲れき裂が半楕円形を保ちながら進展するとすれば，（4 )式により $K$ 值とその変動量をき裂の各位置で求める ことができる。 
$K$ 值の最大值 $K_{\max }$ 拉よび全振幅 $\Delta K$ はき裂の形状と位置で異なるが, き裂の進展速さの表式(( 3 )式)では これらの条件が折り込まれているので，棈円き裂の各位置での進展速さが与えられる。たとえば，Fig. 4 中示 す楕円き裂上の点 $A, B$ ではそれぞれ

$$
\left.\begin{array}{l}
\frac{d a}{d N}=C \frac{K_{\max \cdot \mathrm{A}}}{\Delta K_{\mathrm{A}}} \cdot\left(\Delta K_{\mathrm{A}}\right)^{m} \\
\frac{d b}{d N}=C \frac{K_{\max \cdot \mathrm{B}}}{\Delta K_{\mathrm{B}}} \cdot\left(\Delta K_{\mathrm{B}}\right)^{m}
\end{array}\right\}
$$

ただし，サフィックス A, B はそれぞれの点に対する值であることを示す。

Fig. 3 によれば, 初期切欠の形状が円弧の一部となっているが, き裂進展のごく初期段階で半楕円形状になっ ている。したがって繰返し数 $N$ の增分 $\Delta N$ ごとに( 3 )式を積分し形状を楕円で近似しながら計算を進めれば， $N$ とき裂形状との関係を求めることができる。

$\mathrm{CP}$ 形試験片について試験片で計測された応力を用い, 回数 $N$ の増分 $\Delta N$ を 1,000 として積分を実行し, 疲労 き裂の形状と繰返し数との関係を求めた。な拉 $(3)$ 式を適用するにあたって，材料定数 $C$ おび 方向によらず一定であるとして，室温の AT 形試験片で得られた值を用いた。

計算で得られたき裂の進展の経過を Fig. 3 中に示したが，形状については計算値と実験の結果はかなりよい 一致を示している。しかしながら，繰返し数とき裂寸法との関係は一致せず，板厚貫通までの絽返し数は実駼值 の方が計算值にくらべ5 倍程度大きくなっている。この理由は主として初期切欠から疲労き裂が発生するまでの 期間が大きく影響しているためであり，き裂が進展しはじめてからの進展速さは一応の対応がついているといえ る。

き裂が板厚を貫通してからのき裂進展については，K值を(3')式で求めることはできない。しかしいま仮りに 板厚が無限大の半無限板と考えき裂の各位置での $K$ 值を計算し同様の逐次修正を行ない計算を行なえば, 板厚貫 通前之同様，実験結果とかなりよく合った形状が得られ，回数とき裂寸法についても一応の対応がつけられるこ とがわかったので，Fig. 3 には板厚貫通後のき裂形状を破線で示し参考とした。現状ではこの種の部分貫通した き裂の $K$ 值の算定は困難であるが豊貞らの新しい提案 ${ }^{8)}$ あり今後の課題としたい。

\section{4 構造物の安全性評価に関する考察}

前述のように, 引張と曲げとの組合せ応力を受ける表面き裂の進展挙動について解析し，実験結果を説明でき ることが判ったので, これらの結果をもとに構造物の安全性評価, とくに Leak before failure 条件を検討する うえでの問題点について若干の考察を試みた。

\section{1 初期表面き裂の長さの影響}

初期き裂が板幅方向に長いほど，き裂が板厚を貫通するときの形状は偏平でかつ大きくなると予想される。

供試 A 5083-0 材で厚さ $20 \mathrm{~mm}$, 温度条件室温の場合につき, 初期さ裂寸法の深さbを $2.0 \mathrm{~mm}$ とし表面長 さ $a$ を変化させ, 引張応力のみの繰返し拈よび引張と曲げとの繰返しを受ける場合についてき裂の進展特性を求 め，板厚を貫通するときの表面き裂長さ $a_{t}$ と回数 $N_{t}$ との関係を図示すると Fig. 5 のようである。Fig. 5 によ れば，浅くて長い表面き裂注ど早期に板厚を貫通すること，き裂長さが大きいほど，応力の厚さ方向分布が $a_{t} に$ およぼす影響が小さくなることが判る。

したがって，薄板構造では特に初期き裂長さをいくらに算定するかが,安全性を検討するらえで重要である。

\section{2 工作誤差のある部材の疲労き裂進展}

膜力を受ける構造物に扔いても，角変形やあちがいなどの工作誤差がある場合には，引張応力と同時に曲げ応 力を生じて部材の表面応力が拡大される。したがって, 表面欠陥がある場合には疲労き裂の発生を早めるばかり でなく，き裂の進展速さとき裂貫通時のき裂寸法流影する。

著者らの研究9 によれば，角変形を有する部材が引張を受汀るときの表面特よび裏面のひずみは次式で与えら れる。

ここで

$$
\left.\begin{array}{l}
\varepsilon_{F} \\
\varepsilon_{B}
\end{array}\right\}=\varepsilon_{m}\left\{1 \pm 6\left(1-\nu^{2}\right) \cdot \frac{w_{0}}{t} \cdot \frac{\tanh m}{m}\right\}
$$

$$
m^{2}=12\left(1-\nu^{2}\right) \frac{\sigma_{m}}{E} \cdot\left(\frac{l}{t}\right)^{2}
$$


$\varepsilon_{m}, \varepsilon_{F}, \varepsilon_{B}:$ それぞれ平均ひずみ，表面および裏面のひずみ

$$
\begin{aligned}
2 l & : \text { スパン (両端支持) } \\
t & : \text { 板 厚 } \\
w_{0} & : \text { 初期変形量 } \\
E, \nu & : \text { ヤング率拉よびポアソン比 }
\end{aligned}
$$

また CP 試験片の切欠部の Nominal stress は次式で表わされる。

$$
\left.\begin{array}{l}
\varepsilon_{F} \\
\varepsilon_{B}
\end{array}\right\}=\varepsilon_{m}\left\{1 \pm 6\left(1-\nu^{2}\right) \cdot \frac{\delta}{t} \cdot \frac{D_{1} m_{1} \tanh m_{2} l_{2} / \cosh m_{1} l_{1}}{D_{1} m_{1} \tanh m_{2} l_{2}+D_{2} m_{2} \tanh m_{1} l_{1}}\right\}
$$

ここで

$$
m_{i}{ }^{2}=\frac{12\left(1-\nu^{2}\right) \cdot \sigma_{m}}{E t^{2}}(i=1,2)
$$

$\delta:$ つかみ部と平行部の板厚中心のくいちがい量

$D_{1}, D_{2}:$ 曲げ岡性

$l_{1}, l_{2}:$ 平行部の長さの $1 / 2$, つかみ部長さ

サフィックス 1,2 は平行部とつかみ部に対応する

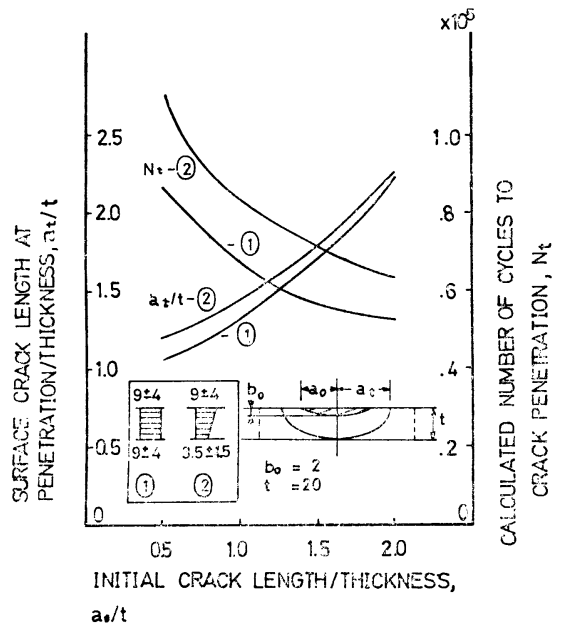

Fig. 5 Geometry of crack front and number of cycles required for crack penetration for different cracks

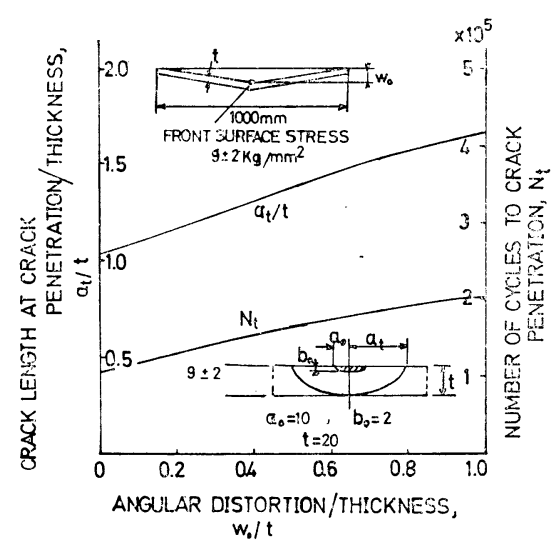

(a) In case $9.0 \pm 2.0 \mathrm{~kg} / \mathrm{mm}^{2}$ is kept on front surface
4.1 と同じ材料を例にとり角変形部に表面き裂がある 場合を想定して, 疲労き裂の進展状況を計算で求める。 (6)式を用い, 角変形 $\left(w_{0} \mathrm{~mm} / 1,000 \mathrm{~mm}\right)$ をかえて表 面扎よび裏面の応力とその変動量を求めて, き裂の進展 の計算を行なった。Fig. 6 (a) には角変形の凹面側応力 を $9 \pm 2 \mathrm{~kg} / \mathrm{mm}^{2}$ の一定変動とした場合，（b）には軸応 力を $4.5 \pm 1 \mathrm{~kg} / \mathrm{mm}^{2}$ とした場合のき裂貫通の㥞相を示 した。

表面応力条件が一定であれば角変形が大きいほど $N_{t}$ は大きいが, 幅方向の広がりが大きくなり, 角変形 $w_{0}$ $=0$ のとき $a_{t} / t \doteqdot 1.1$ であるのに対し, $w_{0}=20 \mathrm{~mm}\left(w_{0} /\right.$ $t=1.0)$ のときは $a_{t} / t \doteqdot 1.7$ となっている。一方, 軸力 の条件を一定としたものは， $w_{0}=0$ の場合にくらべ $w_{0}$ $=20 \mathrm{~mm}$ の場合の $N_{t}$ は約 $1 / 3$ となり安全性が小さく なる。また表面き裂長さ $a_{t} / t \doteqdot 1.7$ と幅方向に広がって いる。

ここで取扱った材料は破填鞁性が十分高いので, ここ

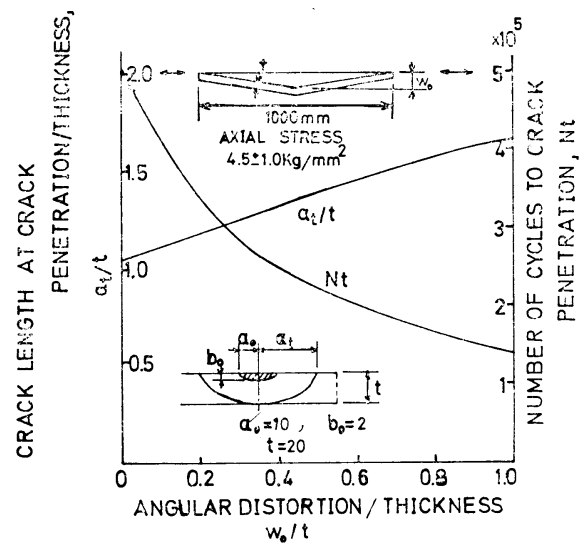

(b) In case axial stress is kept at $4.5 \pm 1.0 \mathrm{~kg} / \mathrm{mm}^{2}$

Fig. 6 Calculated surface crack propagation in a structure with angular distortion 
で取扱った応力条件ではいずれる Leak before failure の条件を満足することになるが，靱性の低い材料では膜 構造であっても工作䛊差あるいは板厚の不連続がある場合には曲げを生じるので漏れを生じる前に不安定き裂寸 法に達することがあり得る。また厚板構造では, 板厚を貫通するときのき裂寸法が相対的に大きくなるので, 応 力の板厚方向に対する分布と変動を考慮に入れて設計応力あるいは材料選定することが必要であろう。

\section{5 結論}

A 5083-0 材の疲労き裂進展特性を調ベるため板厚貫通切欠試験片（AT 形試験片）を用いて基礎試験を行な い,ついで表面切欠試験片により，引張と曲げとの組合せの変動応力を受ける場合の試験を行なった。これらの 試験結果を解析し以下に述べる結論を得た。

（1）板厚貫通切欠試験片の疲労き裂進展速さの試験結果は, 平均応力の影響を考慮した式

$$
d a / d N=C\left(K_{\max } / \Delta K\right) \cdot(\Delta K)^{m}
$$

で整理でさた。

（2）引張と曲げとの組合せ变動応力を受ける表面疲労き裂は半棈円形に進展し，曲げ成分が大きい㴗ど幅方 向への進展が大きくなる。

（3）引張と曲げとの組合せ変動応力を受ける表面き裂の進展特性は（３）式と Kobayashi らの表面半楕円き 裂について求めた $K$ 值を用い逐次数值積分を行ならことにより表わすことができる。

（4）以上の結果から液体貯槽などの安全性を Leak before failure の条件に基ついて検討する場合の問題 点について考察を行なった。

謝 辞

この研究にあたっては, 造船学会溶接研究委員会第一分科会主査金沢武教授をはじめ委員各位から有益なご教 示,ご討論を賜わった。ここに深く謝意を表します。また研究実施の機会を与えられましたことについては石川 島播磨重工業 (株) 技術研究所藤田勇一，後藤大三氏ならびに実験の遂行に際し，多大の支援をいたたいた阪野 賢治，小林頼光氏に感謝します。

\section{参考文 献}

1）金沢武，町田進，系賀興右：表面欠陥からの疲労亀裂伝播特性について(第 1 報)，日本造船学会論文集第 132 号 (1972), p. 395.

2) P.C. Paris and F. Erdogan : A Critical Analysis of Crack Propagation Laws, Trans. ASME Ser. D, Vol.85, (1963), pp. 528 534.

3) L. Tall : Initial Findings from a Study in Low Cycle Fatigue of Welded ASTM A 514 Steel, Fatigue of Welded Structures Conf. (1970).

4) 豊貞雅宏：部分片振領域に括ける疲労龟裂伝播速度について，日本造船学会論文集第 133 号 (1973), p. 209.

5）的場正明，広川紀夫：Tanker の直線式肘板の疲労強度に関する研究，日本造船学会論文集第 132 (1972), p. 429 .

6) Uchimoto et al. : Study on Fatigue Crack Propagation in Aluminum Alloy Sheet, M. T. R. Vol. 7 , No. 5 .

7) R. C. Shah, A.S. Kobayashi : Stress Intensity Factor for an Elliptical Crack Approaching the Surface of a Plate in Bending (to be published in ASTM STP 513 part 1).

8）金沢他：引張応力と面外曲げ応力の組合せ下での貫通き裂の疲労き裂伝播速度について，日本造船学会溶 接研究委員会第一分科会資料.

9) Akita, Y. et al. : Effect of Angular Distortion in Welded Joints on Brittle Fracture Initiation, IIW Doc. X-569-70, (1970). 